\title{
Minority Shareholders' Legal Protection in a Limited Liability Company System
}

\author{
I Gde Sukarmo, Hayyanul Haq, \\ Zainal Asikin and Salim HS* \\ University of Mataram \\ Mataram, Indonesia
}

Received 11.02.2021, received in revised form 30.08.2021, accepted 14.09.2021

\begin{abstract}
The purpose of this study is to determine the legal protection model for the majority and minority shareholders in public limited companies. This research method is normative research. To investigate the ineffectiveness of laws and regulations, in particular, Law No. 40 of 2007 on limited liability companies in providing shareholder protection, researchers have studied the laws and regulations and considered the views of experts on legal concepts related to legal protection for shareholders, particularly, minority shareholders. The results showed that the law did not provide maximum legal protection for minority shareholders, creating an imbalance between the rights of the minority and majority shareholders. For this reason, 1) reform or progressive changes in laws and regulations are needed, for instance, in PT Law No. 40 of 2007. These changes should be fundamental to philosophical aspects (values and perspectives) in providing shareholder protection; 2) the review of shareholders' protection methods should be based on the aspects of fairness.
\end{abstract}

Keywords: protection, reform, minority shareholders.

Research area: law.

Citation: Sukarmo, I.G., Haq, H., Asikin, Z., HS, S. (2021). Minority shareholders' legal protection in a limited liability company system. J. Sib. Fed. Univ. Humanit. soc. sci., 14(11), 1606-1612. DOI: $10.17516 / 1997-1370-0843$

(C) Siberian Federal University. All rights reserved

* Corresponding author E-mail address: hamidi@unram.ac.id 


\author{
И.Г. Сукармо, Х. Хак, З. Асикин, С. ХС \\ Университет Матарама \\ Индонезия, Матарам
}

\begin{abstract}
Аннотация. Целью данного исследования является определение модели законной защиты мажоритарных и миноритарных акционеров публичных обществ с ограниченной ответственностью. Метод исследования - изучение нормативных документов. Для оценки недостатков законов и нормативных актов, в частности закона № 40 от 2007 г. об обеспечении защиты акционеров обществ с ограниченной ответственностью, были изучены законы, нормативные акты, а также учтены мнения экспертов о юридической концепции законной защиты акционеров и миноритарных акционеров в частности. Исследование показало, что закон не обеспечивает миноритарных акционеров максимальной законной защитой, создавая тем самым дисбаланс между правами миноритарных и мажоритарных акционеров. По этой причине: 1) имеется потребность в реформировании или внесении прогрессивных изменений в законы и нормативные акты, в частности в закон № 40 от 2007 об иностранных обществах с ограниченной ответственностью, с целью оказания радикального влияния на основополагающие аспекты (ценности и перспективы) защиты акционеров; 2) методы защиты акционеров должны пересматриваться в свете понятия справедливости.
\end{abstract}

Ключевые слова: защита, реформирование, миноритарные акционеры.

Научная специальность: 12.00 .00 - юриспруденция.

\section{Introduction}

Legal protection for minority shareholders in a limited liability company is a legal issue that is always interesting and up to date for discussion. Various legal regulations have been issued; the most recent one is Law Number 40 of 2007 concerning Limited Liability Companies, also known as the PT. However, over time, the existence of this law for approximately 13 (thirteen) years of its validity period, there are still drawbacks that need immediate correction. As a result of the 2018 EODB survey conducted by the World Bank in 2017, Indonesia was ranked $72^{\text {nd }}$ out of 190 countries in the world (Setianto, 2020). The EODB indicator that is directly related to the UUPT is starting a business (Sinaga, 2017), protecting minority investors (Nan$\mathrm{da}, 2017$ ), and resolving insolvency (Asmara et al., 2019).

Shareholders are one of the components (stakeholders) in a company in addition to oth- er components (stakeholders) such as workers, creditors, investors, consumers, and the wider community who have an interest in the company (Yunia, 2018). More than that, real shareholders are the funders for the sustainability of the company's activities (Wahidah \& Iman, 2019) Tbk by using the EVA method, in order achieve magnitude of the creation economic value added and to see level of return desired by investors. Research method used in this study is a qualitative method and is descriptive with a quantitative approach where there are no samples or populations, because researchers are looking for problems that exist in PT. Adaro Energy, Tbk for the period of 2011-2017 using the method of Economic Value added (EVA. Thus, in addition to being stakeholders, shareholders are also often referred to as bagholders (Hapsari et al., 2020). Because of its important position, it is only natural that the law should guarantee the 
protection of shareholders in a company at any time.

As followed by the PT Law, there are two types of shareholders in company management practice: majority and minority shareholders. This distinction often creates conflicts of interest between shareholders and leads to legal issues (Li et al., 2020); (Zakiyah, 2017). As a rule, minority shareholders only act as a complement in the company. Therefore, it can be ascertained that in the decision-making mechanism, these minority shareholders will always lose to the majority because the decision-making is done based on the percentage of shares owned. This situation gets worse if a majority shareholder happens to use this opportunity to control the company based on their interests alone and does not consider the interests of the minority.

There is a tendency for the majority shareholder to take advantage of their position irresponsibly through the general meeting of shareholders based on the one share one vote principle, or dominating through the Board of Directors, which is in favour of the majority shareholder, causing the company to act as a tool for the benefit of the majority who do not have good faith.

Another form of majority shareholders' domination is the company's directors or commissioners (Supriatna \& Ermond, 2019). If it has caused any moral hazard, the corporate veil can be opened with the help of an agency that identifies a company as causing harm to its minority shareholders, other stakeholders, or the company itself. Majority shareholder abuse also occurs in company liquidation when the reason for such dissolution or liquidation is not transparent enough. In this context, the law must guarantee the protection of the company's shareholders (La Porta et al., 2007); (Haryono, 2016). Legal protection can be provided through various concepts, methods, and theories that will form the foundation for the formulation of positive law acting as legitimacy for the legal protection of company shareholders, especially the minority. Law aims to integrate and coordinate various interests in society, as certain interests can be often protected by limiting the interests of other parties
(Wendur et al., 2020). The interest of law is to take care of human rights and interests, which means that the law has the highest authority to determine human interests that need to be regulated and protected (Nawawi, 2019).

Legal protection of a company's minority shareholders is essential because the shareholders and stakeholders have distributed their rights, obligations, and authorities proportionally. However, it is only possible when the shareholders and management of the company uphold the ethics and principles of justice that underlie the behaviour standards of the individual shareholders. These principles must be legally established to be followed as rules of the game in running the company. The principle of justice in legal protection requires the highest power to be given to the general meeting of shareholders (Permatasari, 2014), where the majority vote (majority share) determines the decision, but the minority shareholders still have their guaranteed rights.

Therefore, justice can be reached with a balance: the minority shareholders can still enjoy their rights as much as the majority and contribute to regulating the company. But, on the other hand, even minority shareholders need their interests to be considered and their rights not simply ignored. To safeguard the interests of both parties, the company should stick to the majority rule \& minority protection principle, which means that the majority remains the ruler of the company, but the power of the majority party is exercised by always protecting the minority. If this situation remains unnoticed by the government, it may disrupt the investment climate and kill small investors.

\section{Method}

The research method used in this research is the normative legal research method, which is legal research that examines legal rules aimed at identifying and describing legal aspects related to legal protection for minority shareholders.

\section{Result And Discussion}

In any situation, the presence of law must realize three fundamental values, namely the value of justice, certainty, and utility value 
(Purwanto, 1993). Achieving the synergy of these values is certainly not easy; however, in a perfect scenario, every legal product must be prepared, and every law must be enforced in a well-balanced proportion of the three. Thus, a good law is a law that contains the principles of sustainability (Dernbach \& Mintz, 2011), justice, and democracy (Bedner, 2010); (Hayat, 2015).

The value of justice is a measure of the fairness of the law (Rismawati, 2015). Apart from that, the value of justice also forms the basis of the law as such. Thus, justice has a normative and constitutive character for the law (Jovanov \& Velinov, 2019). It is normative because it functions as a transcendental prerequisite that underlies any dignified positive law (Harun, 2019). It becomes the moral foundation and yardstick of positive law (Burns, 1998). It is constitutive because justice must be an absolute element of law as law (Mubayyinah, 2019); (Kelsen, 1948). Thus, justice is basically the essence of law in the human world, guaranteeing justice (Kabrtova et al., 2012).

As far as this paper is concerned, the author is interested in examining several provisions or articles in the PT Law closely related to legal protection for shareholders, predominantly the minority. These articles are related to the stages or procedures that shareholders must follow in fighting for their rights. At least several steps or processes are passed, starting from identifying deviations against the rights of minority shareholders, classification of types of customers, analysis, examination, and decision.

Article 138 paragraph (1) of the PT Law confirms that minority shareholders can apply for an examination of the company on the suspicion that the Board of Directors has committed an illegal act. The aforementioned action is an effort that shareholders can make to identify suspected violations of shareholder rights. The purpose of the examination is to obtain information related to the alleged existence of illegal acts that harm shareholders or third parties, or a member of the Board of Directors or the Board of Commissioners committed an unlawful act that harmed the company, its shareholders, or a third party.
Data or information sought and obtained from the examination results is used as evidence to clarify whether or not the alleged illegal act committed by the Board of Directors is a process that can be categorized as an identification process for suspected violations of the rights of minority shareholders. This identification is the first step in obtaining information/ data from the company to assess whether there has been a deviation/violation that could harm the rights of shareholders. If the examination results reveal any facts about the occurrence of unlawful acts that may harm the interests of shareholders, then the examination results can be used as evidence stating that the Board of Directors has committed an illegal act.

According to Article 1915 of the Civil Code, it is affirmed that the allegations are the conclusions made by law or by the judge, connecting a well-known incident to an unknown event. There are two kinds of allegations, namely the ones based and not based on the law. Article 1916 of the Civil Code states that allegations based on the law are suspicions that rely upon a particular provision of law connected with specific actions or events.

The allegations that qualify as valid evidence must be a conclusion drawn from an event or an action committed; the drawn conclusion must indicate any elements of unlawful acts committed by the Board of Directors. The allegations that meet the requirements for request submission must at least have the evidence required for the Company examination to obtain valid evidence in the form of documents, testimony of witnesses or experts, as preparation for filing a lawsuit based on Article 1365 of the Civil Code against the Board of Directors.

Regarding the classification of violations and looking at the provisions of chapter IX of the Company Law, two possibilities can be found. Firstly, the action may qualify as an illegal act or not qualify as such. As stipulated in Article 139 paragraph (1) of the PT Law, the Chairman of the District Court can accept or reject the request for the company examination. If the company examination request is issued, the Head of the Court shall appoint at least three expert teams to carry out the examination. 
The expert team appointed by the Head of the Court has the right to examine and analyze all company documents and company assets as deemed necessary. In the analysis and examination process, the expert team can request information from all related parties such as the Board of Commissioners, Directors, and company employees and, for that, the Commissioners, Directors, and employees are required to provide all the information required by the expert team in carrying out their duties.

Article 140 paragraph (1) of the Company Law states that after the examination, the examiner is obliged to make a report on the examination results that cannot be disclosed to any other parties but must be submitted to the Chair of the District Court within ninety days. The Head of District Court must provide a copy of the examination result report to the applicant (minority shareholder) and the Company concerned based on Article 140 paragraph (2) PT Law no later than 14 days from when the result report was received. If the Head of the District Court receives the results of an examination conducted by a team of experts appointed as stipulated in Article 139 paragraph (3), the Chairman of the Court shall provide a copy of the examination report to the applicant and the company within 14 days.

Observing the provisions of Article 140 paragraph (2), the author concludes that the District Court does not have the authority to issue decisions on violations based on the report of the appointed expert team. The court is only obliged to submit an examination report to the applicant and the company. According to the author, this provision does not provide certainty to shareholders in fighting for their rights because the judge returns the results of the examination report and submits the settlement of the matter to the company internally. Thus, the following process will depend on the applicant. According to the author, it is necessary to carry out a legal reform that can protect shareholders because the law, including the PT Law, results from human effort, including social, political, and cultural construction (Rahayu et al., 2019).

This effort includes the procurement of doctrines, principles, and other parts of it. The existence of law in society aims to serve the in- creasingly complex interests of society. Law as an ideal is closely related to the conceptualization of justice, but it turns out that law cannot operate with abstract concepts alone. The law can only work through human assistance. The claims for a sense of justice in judges' decisions are caused by how the legal, moral and legal frameworks relate to politics. Good law is a law that can accommodate and provide a sense of justice to the people it governs (Allan, 2009) not only how the content of law is determined, but also why the law - in ordinary cases - imposes an obligation of obedience. The theory (as presented. Good law is a law that reflects living values (Goesniadhie, 2010); (Christiani, 2016); (Mahanani, 2019).

Eugen Ehrlich in Hertogh (2016) recommends carrying out legal reform through legislation with the awareness to pay attention to the realities that live in society. These facts are called living and just law, which is the inner order of society reflecting the values that live in it. If one wants to make changes to the law or make a law so that the law or laws that are made can be accepted and applied effectively in the community's life, then something that deserves attention is the law that lives in that society. If this does not get attention, it consequently means that the law cannot be effective and will be challenged.

Legal reform, especially in the field of limited liability companies as one of the pillars of the national economy in a global context, is critically needed as a form of state appreciation in providing protection for all communities and in the context of realizing the people's welfare and prosperity. Building a professional business world and prioritizing the principle of equality/balance is a factor that determines the success or failure of development. The direction of development in the economic sector is the government's obligation to provide direction and guidance in developing the business world and creating a good business climate that encourages economic growth.

\section{Conclusion}

The existence of the PT Law has not been maximal in providing legal protection for minority shareholders. Therefore, legal reform, 
especially the PT Law, is necessary. One of the critical points that must be reformed in the PT Law is the provision regarding the results of the examination of the company due to the alleged illegal activity by the company. Article 140 paragraph (2) of the PT Law emphasizes that district courts are only given the authority to submit reports on the results of examinations of suspected illegal acts to the applicant and the company. This provision does not give the court the authority to give a verdict on the violation based on the report of the appointed expert team. The matter was handed back to the company to be followed up internally. The examination results should be the basis for the court to state that the reported party has committed an illegal act so that it can proceed to the following legal process without going through a lawsuit. This is important to reduce procedures that have had to go through a lengthy process. Therefore, in the context of reforming the PT Law, there must be provisions that regulate or authorize the court to issue a definitive decision on the existence of an illegal act. Thus, legal protection guarantees for shareholders, especially minority shareholders, can be realized.

\section{References}

Allan, T. R. S. (2009). Law, Justice and Integrity: The Paradox of Wicked Laws. Oxford Journal of Legal Studies, 29(4), 705-728. http://www.jstor.org/stable/27750071

Asmara, T. T. P., Ikhwansyah, I., \& ... (2019). Ease of Doing Business: Gagasan Pembaruan Hukum Penyelesaian Sengketa Investasi di Indonesia. University Of Bengkulu Law Journal, 4(2), 118-136.

Bedner, A. (2010). An Elementary Approach to the Rule of Law. Hague Journal on the Rule of Law, 2(1), 48-74. https://doi.org/10.1017/S1876404510100037

Burns, T. (1998). Aristotle and Natural Law. History of Political Thought, 19(2), 142-166. http://www. jstor.org/stable/26217500

Christiani, W. (2016). Hukum Sebagai Norma Sosial Memiliki Sifat Mewajibkan. ADIL: Jurnal Hukum, 4(1), 151-167. https://media.neliti.com/media/publications/53701-ID-none.pdf. Diakses 12 Oktober 2018

Dernbach, J. C., \& Mintz, J. A. (2011). Environmental laws and sustainability: An introduction. Sustainability, 3(3), 531-540. https://doi.org/10.3390/su3030531

Goesniadhie, K. (2010). Perspektif Moral Penegakan Hukum Yang Baik. Jurnal Hukum Ius Quia Iustum, 17(2), 195-216. https://doi.org/10.20885/iustum.vol17.iss2.art2

Hapsari, P. I., Sihabudin, S., \& Santoso, B. (2020). Perlindungan Hukum Para Pemegang Saham Dalam Proses Permohonan Pembubaran Perseroan Terbatas Kepada Pengadilan: Studi Putusan Nomor: 534 K/ Pdt/2014. Jurisdictie, 10(2), 232. https://doi.org/10.18860/j.v10i2.7363

Harun, M. (2019). Philosophical Study of Hans Kelsen's Thoughts on Law and Satjipto Rahardjo's Ideas on Progressive Law. Walisongo Law Review (Walrev), 1(2), 195-220. https://doi.org/10.21580/Walrev/2019.1.2.4815

Haryono, W. A. (2016). Perlindungan Hukum Terhadap Pemegang Saham Minoritas Dalam Peralihan Saham Dengan Akta Pengakuan Utang (Legal Protection on Minority Shareholders in the Share Transfer By Debt-Recognition Deed). Jurnal IUS (Kajian Hukum Dan Keadilan).

Hayat, H. (2015). Keadilan Sebagai Prinsip Negara Hukum: Tinjauan Teoritis dalam Konsep Demokrasi. PADJADJARAN Jurnal Ilmu Hukum (Journal of Law), 2(2), 388-408. https://doi.org/10.22304/pjih.v2n2.a10

Hertogh, M. (2016). Your rule of law is not mine: rethinking empirical approaches to EU rule of law promotion. Asia Europe Journal, 14(1), 43-59. https://doi.org/10.1007/s10308-015-0434-x

Jovanov, R., \& Velinov, M. (2019). Constitutive Justice and Human Rights. PHILOSOPHY AND SOCIETY, 30(4), 463-644. https://doi.org/https://oi.org/10.2298/FID1904478J

Kabrtova, A., Djordjevic, A., Margaria, A., (Axhanela), A., Atilgan, A., Fernandez, C., Schaepelynck, C., Csuka, M., Michels, D., Trifu, D., Capone, F., Stehlik-Barry, L., Schaap, M., Bogicevic, M., Hoepel, O., \& Lachowski, T. (2012). International Journal of Rule of Law, Transitional Justice and Human Rights, Year 2, Volume 2. International Journal of Rule of Law, 2(August 2015). 
Kelsen, H. (1948). Law, State and Justice in the Pure Theory of Law. The Yale Law Journal, 57(3), 377-390. https://doi.org/10.2307/793234

La Porta, R., Lopez-de-Silanes, F., Shleifer, A., \& Vishny, R. W. (2007). Investor protection and corporate governance. Corporate Governance and Corporate Finance: A European Perspective, 58, 91-110. https://doi.org/10.4324/9780203940136

Li, X., Wang, Y., \& You, H. (2020). Executive compensation and conflict between shareholders and creditors: Evidence from creditor litigation. China Journal of Accounting Research, 13(4), 405-424. https://doi.org/https://doi.org/10.1016/j.cjar.2020.07.001

Mahanani, A. E. E. (2019). Rekonstruksi Budaya Hukum Berdimensi Pancasila. Jurnal Yustika Media Hukum Dan Keadilan, 22(1), 1-10. http://journal.ubaya.ac.id/index.php/yustika/article/view/1954/1655

Mubayyinah, F. (2019). Legal Review Of Indefinite Revocation Of The Political Right To Hold Public Office Against Corruption Convicts. Prophetic Law Review, 1(1). https://doi.org/10.20885/plr.vol1.iss1.art6

Nanda, D. A. (2017). Pengaruh Ease of Doing Business dan Business Confidance Terhadap Global Competitiveness Index (Studi pada Negara Amerika Serikat, China, dan Indonesia Tahun 2005-2017). Jurnal Administrasi Bisnis, 62(2), 194-203.

Nawawi, J. (2019). Perlindungan Hukum Terhadap Profesi Guru Dari. Jurnal Al-Adalah: Jurnal Hukum Dan Politik Islam, 4, 159-172.

Permatasari, P. (2014). Perlindungan Hukum Pemegang Saham Minoritas Perusahaan Terbuka Akibat Putusan Pailit. SALAM: Jurnal Sosial Dan Budaya Syar-I, l(2). https://doi.org/10.15408/sjsbs.vli2.1547

Purwanto. (1993). perwujudan keadilan sosial dalam negara hukum Indonesia. In FH-Uiversitas Panca Bhakti Pontianak.

Rahayu, D. P., Faisal, F., \& Tony, T. (2019). Institutions In Legal Systems As Embodiments Of Legal Purposes. Unram Law Review, 3(2). https://doi.org/10.29303/ulrev.v3i2.83

Rismawati, S. D. (2015). Menebarkan Keadilan Sosial dengan Hukum Progresif di Era Komodifikasi Hukum. Jurnal Hukum Islam, 13(1), 1-12.

Setianto, T. (2020). Ease of Doing Business in Indonesia: a Long Road. Optimum: Jurnal Ekonomi Dan Pembangunan, 10(2), 87. https://doi.org/10.12928/optimum.v10i2.15012

Sinaga, E. J. (2017). Upaya Pemerintah Dalam Merealisasikan Kemudahan Berusaha di Indonesia (The Government Eforts In Realizing Ease of Doing Business in Indonesia). Jurnal Rechtsvinding, 6(3), 329-348. http://rechtsvinding.bphn.go.id/artikel/02 Edward James.pdf

Supriatna, A., \& Ermond, B. (2019). Peran Direktur Independen Mewujudkan Good Corporate Governance. Jurnal Yuridis, 6(1), 67-93.

Wahidah, N., \& Iman, L. (2019). Analisis Kinerja Keuangan Menggunakan Metode Economic Value Adedd. Ilmu Manajemen Dan Akuntansi Terapan, 10(1), 4-7.

Wendur, R. S., Kalolo, M. E., \& Soeikromo, D. (2020). Perlindungan Hukum terhadap Pelaku Usaha Mikto, Kecil, dan Menengah di Bidang Ritel di Kota Manado. Lex Administratum, VIII(2), 5-18.

Yunia, D. (2018). Pengaruh Konsentrasi Kepemilikan, Komisaris Independen, Dan Kualitas Audit Terhadap Earning Per Share (Eps). Jurnal Riset Akuntansi Terpadu, 11(1), 1-11. https://doi.org/10.35448/ jrat.v11i1.4159

Zakiyah, T. (2017). Analisis konflik Agency Teory dan pengaruhnya terhadap kebijakan Dividen pada perusahaan yang tergabung dalam LQ 45 (Studi kasus tahun 2011-2015). Jurnal Ilmiah Akuntansi Dan Keuangan, 6(1), 1-28. https://doi.org/10.32639/jiak.v6i1.124 